\title{
Changes in the Signature of Cobalt Colorants in Late Antique and Early Islamic Glass Production
}

\author{
Bernard Gratuze * (D), Inès Pactat and Nadine Schibille * (D) \\ IRAMAT-CEB, UMR5060, CNRS/Université d'Orléans, 3D, rue de la Férollerie, 45071 Orléans CEDEX 2, France; \\ ines.pactat@gmail.com \\ * Correspondence: gratuze@cnrs-orleans.fr (B.G.); nadine.schibille@cnrs-orleans.fr (N.S.); \\ Tel.: +33-02-3802505249 (B.G.); +33-02-3802505212 (N.S.)
}

Received: 27 March 2018; Accepted: 19 May 2018; Published: 25 May 2018

\begin{abstract}
Prior to the eighteenth century, cobalt was exclusively employed as a colouring agent for vitreous materials, and its use appears to be concurrent with the earliest large-scale production of glass during the Late Bronze Age (LBA). LBA cobalt deposits with a distinctive elemental signature have been identified in the oases of the western Egyptian desert, while cobalt mines in Kashan (Iran) and in the Erzgebirge (Germany) are known to have been exploited during the later Middle Ages. For most of the first millennium BCE and CE, however, the identity of cobalt sources and their supply patterns remain elusive. The aim of this study is to characterise the chemical composition of cobalt colorants used during the first millennium CE. Compositional variations indicate the use of different raw materials and/or production processes, which in turn has implications for the underlying exchange networks. Using mainly correlations between cobalt, nickel and zinc as discriminants, our results show that the compositional signature of cobalt underwent two major changes. An increase in the $\mathrm{CoO} / \mathrm{NiO}$ ratios occurs between the late fourth and the beginning of the sixth century, while a new zinc-rich source of cobalt begins to be exploited during the second half of the eighth century in the Islamic world.
\end{abstract}

Keywords: Roman glass; Islamic glass; Byzantine glass; Merovingian glass beads; Viking glass beads; cobalt colorant signature; nickel contents; zinc contents

\section{Introduction}

The use of cobalt as a colorant for vitreous materials appears to have more or less coincided with the advent of the large-scale production of glass during the Late Bronze Age (LBA) both in Egypt $[1,2]$ as well as in Mesopotamia [3]. Popular during the eighteenth dynasty, the production of glass coloured with cobalt declined at the beginning of the nineteenth dynasty [1]. In the European Iron Age, deep blue glass became the prevailing colour for the production of Celtic beads and bracelets from the time of La Tène $C[4,5]$. Cobalt is exceptional among the glass colorants, because in contrast to other colouring elements such as iron, copper, antimony, tin, lead and manganese, cobalt was exclusively used for its colouring properties. No application other than the colouring of glass, faience and ceramic glazes is known for this transition metal prior to its identification by the Swedish chemist Georg Brandt in 1735. Cobalt occurs in nature in three main forms, either as an impurity of manganese ores such as asbolane $\left((\mathrm{Ni}, \mathrm{Co})_{2-\mathrm{x}} \mathrm{Mn}^{4+}(\mathrm{O}, \mathrm{OH})_{4} \cdot \mathrm{nH}_{2} \mathrm{O}\right)$ or as sulphides $\left(\mathrm{CoAsS}, \mathrm{Co}_{3} \mathrm{~S}_{4}\right)$ and arsenide $\left(\mathrm{CoAs}_{2-3}\right)$ that are usually associated with iron, copper or silver ores. Cobalt can also be enriched in some sedimentary deposits such as the alums found in Egyptian oases. Whatever its origin and mineralogical nature, the use of cobalt as a colouring agent in glass and ceramic workshops implies the establishment of extraction processes and refinement techniques. Unfortunately, no textual sources 
survive that describe these ancient processes. The only evidence we have comes from the material itself, specifically the compositional differences between colourless and cobalt coloured glasses.

Its specific use and association with a limited number of elements make cobalt ideal to differentiate production patterns and supply networks. The compositional characteristics and possible origins of cobalt through the ages have therefore been the subject of numerous archaeometric investigations. Excluding south and southeast Asia [6] and concentrating on the Mediterranean world, one of the earliest cobalt sources exploited were the cobaltiferous alum deposits of the oases in the western Egyptian desert [2,7]. This type of cobalt is easily recognised as it is associated with elevated levels of nickel, zinc, manganese as well as alumina, magnesia and iron. The latest recorded use of cobalt extracted from these alums dates to the early Iron Age [8]. It was in fact long thought to have been the only cobalt source used during the LBA in Egypt as well as in the Near East. Additional cobalt sources have since been identified in connection with Mesopotamian glasses [3] as well as glass artefacts and faience from Ramesside Egypt [1]. Compared to the cobalt derived from the alums in Egypt, the Mesopotamian cobalt-coloured glasses have on average substantially higher levels of cobalt and lower nickel, zinc and manganese contents [3], while the Ramesside cobalt differs in terms of its elevated nickel concentrations [1].

In the western world, another type of cobalt characterised by high nickel and arsenic contents was used by the glassworkers in Frattesina during the LBA and early Iron Age [9]. This cobalt was probably a by-product of copper smelting and may have originated in central Europe from where metallurgists used to get their supplies of copper ores [9]. A central European origin, more specifically the Erzgebirge (Germany), has also been proposed for the cobalt employed in some Mycenaean glasses [10]. With the exception of some faience beads recovered in the Alsace and dating to the early Iron Age (Ploin and Gratuze, unpublished data), no other evidence for the use of European cobalt is documented until the end of the twelfth century CE [11].

The elemental signatures of these early cobalt colorants are by now relatively well established and have been used to trace the trade of Egyptian and Mesopotamian LBA raw glass and finished products, for example, to Mycenaean Greece [12] and further towards Europe [13]. In contrast, the cobalt ores employed in the following two millennia have not yet been unequivocally identified. Different studies on the Mediterranean I, II and III glass groups produced between the sixth and the fourth centuries BCE bear witness to a fairly complex situation. Published results [14-17] show varying correlations between cobalt, iron, zinc, copper and nickel. These variations suggest either the contemporaneous exploitation of different cobalt-bearing ores or a small-scale exploitation process of a large cobalt mine with different types of cobalt ores, giving rise to a range of colorant compositions. From the third century BCE onwards, correlations between cobalt and manganese have been observed in Celtic [4] and Hellenistic glass [18], suggesting the use of different types of manganese oxides and hydroxides. However, the analyses carried out on Celtic glass objects and Hellenistic raw glass recovered from numerous shipwrecks in the western Mediterranean do not seem to support this hypothesis [5].

Only very few data are available that shed light on the provenance of cobalt ores used by glass workers during the first millennium CE. Despite some attempts to distinguish first millennium cobalt sources based on variations in $\mathrm{CoO} / \mathrm{NiO}$ or $\mathrm{CoO} / \mathrm{ZnO}$ ratios or on the manganese and antimony contents [19-27], the lack of reliable analytical data and the apparent high purity of the cobalt complicate the characterisation of cobalt and its distribution during this period. For the present paper, mostly published and forthcoming data of several glass assemblages dating to the fourth to eleventh century CE were collated and statistically evaluated. The trace element compositions and varying mineral impurities associated with the cobalt colorant were established using laser ablation inductively coupled mass spectrometry (LA-ICP-MS) [28], allowing us to observe chronological patterns and identify several major changes in the supply of cobalt during the late antique and the early Islamic period. These differences in the cobalt source constitute important new evidence for the changes in the production of glass and, by extension, the underlying networks of exchange. 


\section{Materials and Methods}

\subsection{Archaeologial Materials}

The present article is based on almost 500 published and unpublished data of cobalt blue glasses dating to the Roman, late antique and early Islamic period from mostly French collections. The sample includes different types of vessels (mosaic glass, cage cups, bottles, Saint Savin type), beads and bangles, large sets of Byzantine and Islamic glass weights and working debris from various secondary glass workshops (Table 1).

Table 1. Corpus of glass samples on which this paper is based.

\begin{tabular}{|c|c|c|c|}
\hline Type of Glass & Date & Number of Analyses & Cobalt Type \\
\hline Cage cups [30] & 4th century CE & 18 & Roman cobalt low nickel \\
\hline Le Pègue workshop [31] & 2nd-3rd centuries CE & 6 & Roman cobalt low nickel \\
\hline $\begin{array}{l}\text { Besançon workshop [32] } \\
\text { unpublished data }\end{array}$ & 2nd century CE & 9 & Roman cobalt low nickel \\
\hline Merovingian glass beads [33] & 5th-7th centuries CE & 81 & $\begin{array}{l}\text { Roman cobalt low nickel } \\
\text { late antique high nickel cobalt }\end{array}$ \\
\hline Ribe natron glass [26] & 8th century $\mathrm{CE}$ & 38 & $\begin{array}{l}\text { Roman cobalt low nickel } \\
\text { late antique high nickel cobalt }\end{array}$ \\
\hline Beirut workshop [20] & 7th century $\mathrm{CE}$ & 51 & Late antique high nickel cobalt \\
\hline $\begin{array}{l}\text { Grozon workshop } \\
\text { unpublished data }\end{array}$ & 8th century $\mathrm{CE}$ & 19 & Late antique high nickel cobalt \\
\hline Saint-Savin type glass $[24,34]$ & 10th-11th centuries & 32 & Mainly Roman cobalt low nickel \\
\hline $\begin{array}{l}\text { St Denis window panel } \\
\text { unpublished data }\end{array}$ & 12th century CE & 1 & Roman cobalt low nickel \\
\hline Ribe Islamic plant ash glass [26] & 9th-10th centuries CE & 17 & Islamic cobalt-zinc \\
\hline Komani and Lehza glass [23] & 7th-13th centuries CE & $\begin{array}{l}16 \text { Komani plant ash } \\
1 \text { Lehza plant ash } \\
5 \text { Lehza natron }\end{array}$ & $\begin{array}{c}1 \text { Roman cobalt low nickel } \\
4 \text { late antique high nickel cobalt } \\
12 \text { Islamic cobalt-zinc } \\
1 \text { European cobalt-indium-zinc }\end{array}$ \\
\hline
\end{tabular}

\subsection{Analytical Methods}

Most of the analytical data presented or used for discussion in this paper have been obtained at the Institut de Recherche sur les Archéomatériaux (Centre Ernest-Babelon, CNRS/University of Orléans, France) by laser ablation inductively coupled plasma mass spectrometry (LA-ICP-MS). The used instrumentation consists of a Resonetics M50E excimer laser working at $193 \mathrm{~nm}$ and a Thermo Fisher Scientific ELEMENT XR mass spectrometer. The samples either unprepared or as cross-sections mounted in epoxy resin were analysed within the standard Resonetic S155 cell. Some data pre-dating 2009 have been obtained using a VG Plasma Quad PQXS mass spectrometer coupled with a Nd:YAG VG UV Laser Probe ablation sampling device operating at $266 \mathrm{~nm}$. For polychrome objects, each colour was analysed separately by the pulsed laser beam operating at a $5 \mathrm{~mJ}$ energy and a $10 \mathrm{~Hz}$ pulse frequency. The beam diameter can be adjusted from $30 \mu \mathrm{m}$ to $100 \mu \mathrm{m}$ in order to minimise the saturation of the signal by some elements. 
The depth of the crater, typically ranging from 150 and $250 \mu \mathrm{m}$, depends on the ablation duration and the laser pulse frequency. A pre-ablation time is set to ensure the elimination of surface contaminations and corrosions, and to acquire a reliable signal from the unaltered bulk glass. The standard analytical protocol includes a $20 \mathrm{~s}$ pre-ablation followed by $30 \mathrm{~s}$ signal acquisition, which corresponds to 10 mass scans. The sampled aerosol is carried to the injector inlet of the plasma torch by an argon/helium flow (at a rate of $1 \mathrm{~L} / \mathrm{min}$ for $\mathrm{Ar}$ and $0.65 \mathrm{~L} / \mathrm{min}$ for He) where it is dissociated, atomised, and ionised. The ions are then injected into the vacuum chamber of the high-resolution mass spectrometer where they are separated on the basis of their mass-to-charge ratio. The ions are collected by the channel electron multiplier or the Faraday cup. The signal in counts-per-second was measured in low-resolution for 58 isotopes (from Li to U). This analytical protocol allows for the determination of nearly all the elements present in ancient glasses except sulphur:

- the main major and minor ancient glass constituents: silicon, sodium, calcium, potassium, aluminum, magnesium, lead, chlorine, phosphorus and iron;

- most of the colouring and opacifying agents and associated impurities: cobalt, copper, antimony, tin and manganese but also zinc, nickel, arsenic, barium, chromium, vanadium, gold, silver, selenium and cadmium;

- and several other trace elements, including rubidium, strontium, cesium, zirconium, uranium, thorium and the rare earth elements.

External calibration was performed using the National Institute of Standards and Technology Standard Reference Materials 610 (NIST SRM610), along with Corning reference glasses B, C, and D, and the archaeological sample APL1. The latter is an in-house standard glass with a composition determined by fast neutron activation analysis used for chlorine quantification. ${ }^{28} \mathrm{Si}$ was used as an internal standard. Concentrations were calculated according to the protocol detailed in Gratuze [28]. Detection limits range from $0.01 \%$ to $0.1 \%$ for major elements, and from 20 to $500 \mathrm{ppb}$ for minor and trace elements. Compatibility of data is monitored by the regular analyses of reference materials Corning a and NIST SRM612 as unknown samples.

\section{Results and Discussion}

\subsection{Roman Cobalt Ores}

One of the main characteristics of the cobalt colorants used during the first millennium $C E$ is their seemingly high purity. Compared to other coloured and uncoloured glasses, the main distinguishing features of cobalt blue glasses are their higher iron and copper contents. The concentrations of other elements such as manganese or antimony and to a lesser extent nickel, zinc, arsenic, tin and lead may also be elevated. Variations in antimony and manganese levels, however, are probably more related to the raw glass recipes rather than the composition of the colorant, while recycling practices are bound to have an impact on trace elements in general. To determine the chemical signature of the cobalt colorant itself, it is therefore necessary to first reconstruct the composition of the raw glass used for the production of the cobalt-blue glass. This assumption can be difficult to prove in some cases as the mixing and/or recycling of cullet may change the glass composition and increase its variability.

There is good reason to assume that cobalt coloured glasses were made of the same base glass as contemporary non-coloured or decoloured glasses. In a recent study of the vitreous material from the second- to third-century glass workshop of Le Pègue (Drôme, France), we examined the production waste of deep blue and colourless glasses, and found that both derived from similar batches of raw glass [31]. We were thus able to calculate the average composition of the colourless raw glass, and subtract it from the average composition of the blue glass (Table 2). In order to single out the elements associated with the cobalt colorant and to exclude those components that have a high inherent variability, we considered as significant only differences that were superior to two standard deviations of the colourless glass composition. Applying this stringent threshold, the cobalt blue glasses differ 
from the antimony decoloured glass in terms of iron, cobalt, nickel, copper, tin and lead and to some extent gallium, indium and gold (Table 2). These differences represent the likely composition of the colouring agent that, after normalisation, amounts to a mixture of mostly iron (56.6 wt \%), copper $(22.2 \%)$, cobalt $(15.7 \%)$, lead $(5.1 \%)$, nickel $(0.29 \%)$ and tin $(0.064 \%)$, as well as low levels of gallium $(0.034 \%)$, indium $(0.0053 \%)$ and gold $(0.0018 \%)$. The character of the cobalt colorant is best expressed in the form of ratios. For example, the ratio between cobalt and nickel is estimated at 54 in the colorant, or at 39 when calculated for the cobalt blue glass matrix. The amount of iron introduced together with cobalt is about 3.6 times the $\mathrm{CoO}$ content. At this stage, it is not possible to fully ascertain the ratios between cobalt and copper $(\mathrm{CoO} / \mathrm{CuO}=0.71)$, tin $\left(\mathrm{CoO} / \mathrm{SnO}_{2}=245\right)$ or lead $(\mathrm{CoO} / \mathrm{PbO}=3.1)$ because these three elements can derive either from different mineral species associated with the cobalt ores, or they can be added independently as metallic scraps (Table 2).

Similar ratios of cobalt associated elements are expressed in a series of Roman cage cups from Yambol and Serdica (Bulgaria) [30], a two- to third-century glass from the Hospitalet (Larzac, France, unpublished data) and several cobalt blue glass fragments from a second-century glass workshop in Besançon (Table 3). The likely composition of the cobalt colorant in these cases can be estimated by subtracting from the cobalt blue glasses the iron, nickel, copper, tin and lead contents of colourless glass segments within the same object (Hospitalet, Serdica, Yambol and CMoG), or the average of the colourless glass samples from the same workshop (Besançon). It should be noted that the use of data from individual samples necessarily increases the variability in contrast to averaged data. This is relatively unproblematic for nickel, copper, tin and lead, as their overall concentrations in colourless base glass are usually in the order of a few tens of ppm or below. For iron, however, the estimation is less certain, especially when the blue glass is produced from recycled cullet. This complication is illustrated by the results from the Yambol cup, where the ratios between iron and cobalt for two fragments of supposedly the same object varies from 2.4 to 20. The ratios calculated for the other individual samples also range from 3.7 to 16.7 , whereas the $\mathrm{CoO} / \mathrm{NiO}$ ratios are not as strongly scattered around the median value of $29(24<\mathrm{CoO} / \mathrm{NiO}<54)$. These values are very consistent with the $\mathrm{CoO} / \mathrm{NiO}$ ratio of the Le Pègue glasses (Table 2), and it thus appears to represent the principal type of cobalt colorant used during the early imperial period (second to fourth century CE). It should be borne in mind, however, that in some cases the $\mathrm{CoO} / \mathrm{NiO}$ ratio of the colorant may be distorted for low cobalt concentrations due to overall elevated heavy element levels in certain base glass types. For instance, the nickel content in ancient colourless raw glass may vary from a few ppm in antimony decoloured glasses ( $3 \mathrm{ppm}<\mathrm{NiO}<7 \mathrm{ppm}$ ) up to a few tens of ppm in HIMT ( $\mathrm{NiO} \approx 20 \mathrm{ppm}$ ) or Foy-2 high Fe samples $(\mathrm{NiO} \approx 35 \mathrm{ppm})$ [25]. Manganese decoloured glass has nickel contents in the order of 10 to $15 \mathrm{ppm}$. Hence, the apparent $\mathrm{CoO} / \mathrm{NiO}$ ratio in a glass containing only a small amount of cobalt $(\mathrm{CoO}<300 \mathrm{ppm})$ can be severely affected by the underestimation or the overestimation of the natural nickel content of its base glass. Judging from the above data and calculations, the cobalt colorant used by Roman glassworkers until the mid-fourth century was mainly a mixture of iron and cobalt oxides $\left(4<\mathrm{Fe}_{2} \mathrm{O}_{3} / \mathrm{CoO}<10\right)$ that tends to contain low levels of copper $(\mathrm{CoO} / \mathrm{CuO} \approx 0.5)$, which in turn may add traces of tin and lead. These Roman cobalt-coloured glasses have typically high $\mathrm{CoO} / \mathrm{NiO}$ ratios $(24<\mathrm{CoO} / \mathrm{NiO}<54)$. 
Table 2. Calculation of the cobalt colorant based on the difference between cobalt coloured and antimony decoloured Roman glasses from the glass workshop in

Le Pègue (Drôme, France). The calculated composition of the cobalt colorant (blue) is given in wt \% (normalised to 100\%).

\begin{tabular}{|c|c|c|c|c|c|c|c|c|c|c|c|c|c|c|c|c|c|c|c|c|c|c|c|}
\hline \multirow{2}{*}{ Samples } & \multicolumn{10}{|c|}{ wt $\%$} & \multicolumn{8}{|c|}{ ppm } & \multicolumn{5}{|c|}{ Ratios of Metal Oxides } \\
\hline & $\mathrm{Na}_{2} \mathrm{O}$ & $\mathrm{MgO}$ & $\mathrm{Al}_{2} \mathrm{O}_{3}$ & $\mathrm{SiO}_{2}$ & $\mathrm{P}_{2} \mathrm{O}_{5}$ & $\mathrm{Cl}$ & $\mathrm{K}_{2} \mathrm{O}$ & $\mathrm{CaO}$ & $\mathrm{Fe}_{2} \mathrm{O}_{3}$ & $\mathrm{Sb}_{2} \mathrm{O}_{3}$ & ${ }_{3} \mathrm{CoO}$ & $\mathrm{NiO}$ & $\mathrm{CuO}$ & $\mathrm{SnO}_{2}$ & $\mathrm{PbO}$ & $\mathrm{GaO}$ & In & $\mathrm{Au}$ & $\mathrm{Fe}_{2} \mathrm{O}_{3} / \mathrm{CoO}$ & $\mathrm{CoO} / \mathrm{NiO}$ & $\mathrm{CoO} / \mathrm{CuO}$ & $\mathrm{CoO} / \mathrm{SnO}_{2}$ & $\mathrm{CoO} / \mathrm{PbO}$ \\
\hline Cobalt g & 17.1 & 0.45 & 2.18 & 70.5 & 0.036 & 1.07 & 0.57 & 6.15 & 0.82 & 0.62 & 697 & 23 & 1000 & 22 & 476 & 4.9 & 0.24 & 0.11 & 5.9 & 39.4 & 0.70 & 69.7 & 1.60 \\
\hline $\mathrm{SD}($ & 1.1 & 0.02 & 0.18 & 0.7 & 0.002 & 0.07 & 0.09 & 0. & 0.04 & 0.02 & 39 & 4 & 81 & 4 & 86 & 0.3 & 0.01 & 0.03 & & & & & \\
\hline Sb glass $(n=12)$ & 15.5 & 0.41 & 2.07 & 72.9 & 0.038 & 1.16 & 0.47 & 5.97 & 0.41 & 0.78 & 1.6 & 5.3 & 10 & 12 & 41 & 2.9 & 0 & 0.01 & & & & & \\
\hline $\mathrm{SD}(\sigma)$ & 1.7 & 0.08 & 0.15 & 2.6 & 0.012 & 0.09 & 0.14 & 0.85 & 0.08 & 0.12 & 0.5 & 2.6 & 4 & 4 & 105 & 0.2 & 0 & 0.01 & & & & & \\
\hline $\mathrm{Co}-((\mathrm{Sb})+2 \times \sigma(\mathrm{Sb}))$ & & & & & & & & & $\begin{array}{l}0.25 \\
566\end{array}$ & & 694 & 13 & 982 & 2.8 & 224 & 1.5 & 0.24 & 0.08 & & & & & \\
\hline & & & & & & & & & 56.6 & & 15.7 & 0.29 & 22.2 & 0.064 & 5.1 & 0.034 & 0.0053 & 0.0018 & 3.6 & 54.1 & 0.71 & 245 & 3.1 \\
\hline
\end{tabular}

Table 3. Estimated ratios of cobalt and associated metal oxides of selected second- to fourth-century Roman glasses, based on the difference between the average composition of cobalt blue and colourless glass of either the same object (Hospitalet, Serdica, Yambol and CMoG-Corning Museum of Glass) or colourless glasses from the same workshop (Besançon). Two values are given for $\mathrm{NiO}$ in the colourless glasses from Besançon, one (3.1 ppm *) for the glass without manganese $(\mathrm{MnO}<0.02 \%)$ and the other $\left(6.4 \mathrm{ppm}^{* *}\right)$ for glasses containing manganese above the contamination level $(\mathrm{MnO}>0.2 \%)$. These values are subtracted from the corresponding samples of cobalt blue glass (denoted with * and ${ }^{* *}$ ) for the calculation of the $\mathrm{CoO} / \mathrm{NiO}$ ratios.

\begin{tabular}{|c|c|c|c|c|c|c|c|c|c|c|c|}
\hline \multirow{2}{*}{ Samples } & \multirow{2}{*}{$\begin{array}{l}\mathrm{wt} \% \\
\mathrm{Fe}_{2} \mathrm{O}_{3}\end{array}$} & \multicolumn{5}{|c|}{ ppm } & \multicolumn{5}{|c|}{ Ratios of Metal Oxides } \\
\hline & & $\mathrm{CoO}$ & $\mathrm{NiO}$ & $\mathrm{CuO}$ & $\mathrm{SnO}_{2}$ & $\mathrm{PbO}$ & $\mathrm{Fe}_{2} \mathrm{O}_{3} / \mathrm{CoO}$ & $\mathrm{CoO} / \mathrm{NiO}$ & $\mathrm{CoO} / \mathrm{CuO}$ & $\mathrm{CoO} / \mathrm{SnO}_{2}$ & $\mathrm{CoO} / \mathrm{PbO}$ \\
\hline Hospitalet 332002 blue & 1.22 & 1109 & 43 & 2319 & 126 & 4697 & 7.99 & 32.8 & 0.48 & 8.85 & 0.24 \\
\hline Hospitalet 332002 colourless & 0.33 & 5.4 & 9.4 & 6.9 & 0.6 & 5.7 & & & & & \\
\hline Serdica 26 blue & 1.04 & 380 & 21 & 1247 & 111 & 2201 & 10.5 & 25.3 & 0.32 & 4.00 & 0.18 \\
\hline Serdica 27 colourless & 0.64 & 4 & 6 & 43 & 16 & 74 & & & & & \\
\hline Yambol No. $1 / 2$ & 0.88 & 539 & 24 & 848 & 72 & 2608 & 2.44 & 37.5 & 0.69 & 8.31 & 0.21 \\
\hline Yambol No. 5/6 & 1.55 & 400 & 25 & 2793 & 130 & 932 & 20.0 & 25.9 & 0.15 & 3.24 & 0.45 \\
\hline Yambol colourless & 0.75 & 3.9 & 9.8 & 68 & 6.9 & 44 & & & & & \\
\hline CMoG CUP (55.1.143) blue & 0.88 & 429 & 24 & 949 & 27 & 1737 & 5.59 & 25.2 & 0.46 & 18.7 & 0.25 \\
\hline CMoG CUP (55.1.143) colourless & 0.64 & 3 & 11 & 13 & 4 & 28 & & & & & \\
\hline Besançon 3148 B * & 0.78 & 563 & 14 & 980 & 6.0 & 179 & 7.85 & 53.5 & 0.58 & 114 & 3.61 \\
\hline Besançon $3148 \mathrm{D}$ ** & 0.92 & 568 & 27 & 1477 & 71 & 1373 & 10.3 & 27.2 & 0.39 & 8.12 & 0.42 \\
\hline Besançon $3239 C^{* *}$ & 1.01 & 1320 & 59 & 1259 & 45 & 17208 & 5.08 & 25.3 & 1.05 & 30.2 & 0.08 \\
\hline Besançon $3814 \mathrm{~B}$ ** & 0.91 & 1564 & 47 & 1337 & 3.9 & 66 & 3.67 & 38.4 & 1.18 & 552 & 36.7 \\
\hline Besançon 3815 B ** & 0.62 & 379 & 19 & 687 & 31 & 3357 & 7.40 & 30.8 & 0.56 & 12.6 & 0.11 \\
\hline Besancon $3828 a^{* *}$ & 0.70 & 218 & 15 & 546 & 46 & 1234 & 16.7 & 24.1 & 0.40 & 4.90 & 0.18 \\
\hline Besançon $3935 \mathrm{D}^{* *}$ & 0.95 & 902 & 36 & 1758 & 68 & 8834 & 6.81 & 30.4 & 0.52 & 13.6 & 0.10 \\
\hline Besançon colourless & 0.34 & 1.3 & $3.1 * / 6.4 * *$ & 7.33 & 1.07 & 23.5 & & & & & \\
\hline median & & & & & & & 7.6 & 28.8 & 0.5 & 10.7 & 0.23 \\
\hline
\end{tabular}




\subsection{Characteristics of Late Antique Cobalt Colorants}

The $\mathrm{CoO} / \mathrm{NiO}$ ratios of cobalt blue glasses change during the late antique period. Recent analytical data from our laboratory have revealed the existence of cobalt colorants with comparatively low $\mathrm{CoO} / \mathrm{NiO}$ ratios $(3<\mathrm{CoO} / \mathrm{NiO}<10)$ in glasses dating to the sixth and seventh centuries $\mathrm{CE}$. In a comprehensive analytical study of Byzantine glass weights, the cobalt signature was identified by the direct comparison of the chemical profile of two cobalt blue samples of the same base glass, probably deriving from the same batch, but with minor variations in elements related to the cobalt colorant [25]. Using the same computational model as before, the mixture of the colouring agent used for the cobalt blue Byzantine glass weights can be approximated as the difference between the non-coloured and cobalt coloured samples of the same primary glass production group (Table 4). The so-calculated compound in the Levantine I glass weights consists predominantly of iron (34\%), lead $(37 \%)$, copper (about $17.5 \%)$, cobalt $(8 \%)$, nickel $(2.4 \%)$, tin $(0.75 \%)$ as well as minor traces of zinc $(0.13 \%)$, arsenic $(0.2 \%)$, indium $(0.01 \%)$ and molybdenum $(0.06 \%)$. Compared to the Roman cobalt ore, the late antique colorant not only has significantly lower $\mathrm{CoO} / \mathrm{NiO}$ ratios $(\mathrm{CoO} / \mathrm{NiO}<4)$ than in the Roman cobalt glasses, but the ratios of $\mathrm{CoO} / \mathrm{CuO}(\mathrm{CoO} / \mathrm{CuO}=0.45)$, tin $\left(\mathrm{CoO} / \mathrm{SnO}_{2}=10.6\right)$ and lead $(\mathrm{CoO} / \mathrm{PbO}=0.21)$ tend to be substantially lower as well. Even though it cannot be concluded with certainty that these elements are directly associated with the cobalt ore, the fact that they are systematically enriched in the late antique cobalt blue glasses suggests that they are somehow linked to the secondary glass working and colouring processes. It is furthermore worthy of notice that the number and levels of impurities associated with the late antique cobalt colorant was substantially higher than that used during the Roman period.

We have since discovered similar characteristics among late antique mosaic tesserae from Durres (Albania) and Naples [22,36]. This cobalt colorant is also closely related to the cobalt employed in the seventh-century glass workshop in Beirut (Lebanon) and in Merovingian beads from France [20,21,33]. New analyses have been carried out on the blue glass samples from the workshop in Beirut to better characterise the cobalt colorant used by the glass workers. The cobalt blue glass wastes from Beirut are visually very heterogeneous with several black precipitates suspended within the glass matrix, ranging in size from tens to hundreds of micrometers (Figure 1). Reddish or bluish streaks develop from these grains, indicating that they probably represent remains of unfused colorant particles. This gives us the unique opportunity to analyse the cobalt colorant itself, presenting a direct alternative to determine the chemical composition of the colouring agent that is independent of the base glass. Recent LA-ICP-MS analyses on these black aggregates proved that they are composed of a combination of iron, cobalt, nickel and copper, and occasionally zinc and lead but with widely differing concentrations. In some cases, the sum of the four principal oxides $(\mathrm{Fe}, \mathrm{Co}, \mathrm{Ni}, \mathrm{Cu}$ ) in these inclusions exceeds $80 \%$ (Figure 2), complemented by the glass forming oxides $(\mathrm{Na}, \mathrm{Mg}, \mathrm{Al}, \mathrm{Si}, \mathrm{K}, \mathrm{Ca})$ as well as zinc and lead oxides when present (Table 5). The main trace elements detected within the particles are molybdenum, indium, gallium, arsenic, silver, gold and bismuth. Among these, gallium and molybdenum do not seem to be correlated with either cobalt or copper, whereas nickel, arsenic and bismuth exhibit a positive correlation with both (Figure 3). Indium and zinc are correlated only with cobalt, while silver and gold are correlated only with copper. Some correlations seem to exist between zinc, gallium and indium. Within the inclusions that contain more than $1 \%$ cobalt, individual $\mathrm{CoO} / \mathrm{NiO}$ ratios vary between 1.1 and 16.3 , with a median of 4.5 . 
Table 4. Calculation of the cobalt colorant based on the difference between cobalt coloured and non-coloured Byzantine glass weights of the Levantine I compositional group [25]. Cobalt colorant (blue) is given as wt \% (normalised to $100 \%)$.

\begin{tabular}{|c|c|c|c|c|c|c|c|c|c|c|c|c|c|c|c|}
\hline \multirow{2}{*}{ Samples } & \multicolumn{5}{|l|}{ wt $\%$} & \multicolumn{5}{|c|}{ ppm } & \multicolumn{5}{|c|}{ Ratios of Metal Oxides } \\
\hline & $\mathrm{Fe}_{2} \mathrm{O}_{3}$ & $\mathrm{CoO}$ & $\mathrm{NiO}$ & $\mathrm{CuO}$ & $\mathrm{SnO}_{2}$ & $\mathrm{PbO}$ & $\mathrm{ZnO}$ & $\mathrm{As}_{2} \mathrm{O}_{3}$ & $\mathrm{MoO}$ & In & $\mathrm{Fe}_{2} \mathrm{O}_{3} / \mathrm{CoO}$ & $\mathrm{CoO} / \mathrm{NiO}$ & $\mathrm{CoO} / \mathrm{CuO}$ & $\mathrm{CoO} / \mathrm{SnO}_{2}$ & $\mathrm{CoO} / \mathrm{PbO}$ \\
\hline Levantine I cobalt $(n=24)$ & 1.21 & 1097 & 346 & 2575 & 116 & 5209 & 60.4 & 31.4 & 9.49 & 1.30 & 6.29 & 3.24 & 0.43 & 9.76 & 0.21 \\
\hline $\mathrm{SD}(\sigma)$ & 0.27 & 454 & 157.5 & 1473 & 59.2 & 1946 & 56.1 & 17.3 & 4.41 & 0.47 & & & & & \\
\hline Levantine I colourless $(n=25)$ & 0.52 & 2.82 & 7.08 & 32.7 & 3.65 & 23.1 & 16.8 & 3.09 & 0.72 & 0.02 & & & & & \\
\hline $\mathrm{SD}(\sigma)$ & 0.12 & 1.32 & 2.07 & 57.3 & 4.59 & 28.2 & 12.5 & 0.95 & 0.44 & 0.02 & & & & & \\
\hline Co- $(($ colourless $)+2 \times \sigma)$ & 0.47 & 1091 & 335 & 2428 & 103 & 5129 & 18.5 & 26.4 & 7.89 & 1.25 & & & & & \\
\hline cobalt colorant [wt \%] & 33.8 & 7.9 & 2.42 & 17.6 & 0.75 & 37.1 & 0.13 & 0.19 & 0.06 & 0.01 & 4.28 & 3.26 & 0.45 & 10.6 & 0.21 \\
\hline
\end{tabular}

Table 5. Average, maximum and minimum compositions of cobalt colorant inclusions (inc) in glass from the seventh-century workshop in Beirut (Lebanon) and a crucible from the early eighth-century workshop at Grozon (France). The average composition of the colourless and blue or greenish glasses associated with the colorants is given for comparison.

\begin{tabular}{|c|c|c|c|c|c|c|c|c|c|c|c|}
\hline \multirow{2}{*}{ Unit } & \multirow{2}{*}{ Elements } & \multicolumn{5}{|c|}{ Beirut } & \multicolumn{5}{|c|}{ Grozon } \\
\hline & & inc. av $n=24$ & inc. Max. & inc. Min. & $\begin{array}{l}\text { Colourless } \\
\text { Glass } n=7\end{array}$ & Blue Glass $n=27$ & inc. av $n=6$ & inc. Max. & inc. Min. & $\begin{array}{l}\text { Colourless } \\
\text { Glass } n=5\end{array}$ & Green Glass $n=8$ \\
\hline \multirow{16}{*}{ wt $\%$} & $\mathrm{Na}_{2} \mathrm{O}$ & 8.18 & 13.2 & 1.55 & 13.8 & 13.1 & 9.17 & 14.7 & 0.53 & 10.7 & 13.9 \\
\hline & $\mathrm{MgO}$ & 1.15 & 2.55 & 0.37 & 0.78 & 0.79 & 1.22 & 1.99 & 0.62 & 2.23 & 1.42 \\
\hline & $\mathrm{Al}_{2} \mathrm{O}_{3}$ & 4.26 & 9.06 & 1.34 & 3.10 & 3.16 & 10.7 & 14.7 & 4.31 & 5.65 & 5.90 \\
\hline & $\mathrm{SiO}_{2}$ & 37.6 & 63.2 & 7.16 & 70.5 & 69.0 & 35.9 & 55.8 & 3.4 & 64.2 & 64.0 \\
\hline & $\mathrm{P}_{2} \mathrm{O}_{5}$ & 0.068 & 0.12 & 0.0000 & 0.11 & 0.11 & 0.39 & 1.42 & 0.045 & 0.33 & 0.36 \\
\hline & $\mathrm{Cl}$ & 0.38 & 0.80 & 0.099 & 0.89 & 0.82 & 0.17 & 0.26 & 0.090 & 0.055 & 0.11 \\
\hline & $\mathrm{K}_{2} \mathrm{O}$ & 0.45 & 0.93 & 0.038 & 0.75 & 0.79 & 1.50 & 2.45 & 0.19 & 5.00 & 1.95 \\
\hline & $\mathrm{CaO}$ & 4.24 & 8.27 & 1.04 & 9.22 & 9.10 & 1.63 & 3.07 & 0.26 & 7.58 & 5.76 \\
\hline & $\mathrm{TiO}_{2}$ & 0.15 & 0.28 & 0.063 & 0.084 & 0.090 & 0.41 & 0.54 & 0.30 & 0.32 & 0.30 \\
\hline & $\mathrm{MnO}$ & 0.32 & 1.88 & 0.042 & 0.034 & 0.050 & 0.53 & 0.88 & 0.24 & 0.98 & 0.88 \\
\hline & $\mathrm{Fe}_{2} \mathrm{O}_{3}$ & 34.2 & 76.3 & 5.88 & 0.58 & 1.19 & 26.3 & 58.0 & 8.75 & 2.52 & 2.74 \\
\hline & $\mathrm{CoO}$ & 2.96 & 11.7 & 0.13 & 0.0004 & 0.11 & 8.48 & 20.8 & 0.64 & 0.0074 & 0.013 \\
\hline & $\mathrm{NiO}$ & 0.91 & 4.81 & 0.020 & 0.0006 & 0.027 & 2.09 & 5.39 & 0.089 & 0.0054 & 0.019 \\
\hline & $\mathrm{CuO}$ & 3.12 & 26.8 & 0.14 & 0.021 & 0.41 & 0.93 & 1.82 & 0.38 & 0.15 & 2.23 \\
\hline & $\mathrm{ZnO}$ & 0.11 & 0.35 & 0.010 & 0.0014 & 0.011 & 0.19 & 0.49 & 0.023 & 0.025 & 0.020 \\
\hline & $\mathrm{PbO}$ & 1.67 & 5.17 & 0.35 & 0.0074 & 1.08 & 0.062 & 0.13 & 0.025 & 0.016 & 0.14 \\
\hline \multirow{6}{*}{ ppm } & $\mathrm{Li}_{2} \mathrm{O}$ & 8.8 & 18 & bdl & 12 & 11 & 17 & 34 & bdl & 662 & 59 \\
\hline & $\mathrm{B}_{2} \mathrm{O}_{3}$ & 152 & 304 & 25 & 338 & 317 & 218 & 383 & 8.2 & 158 & 361 \\
\hline & $\mathrm{V}_{2} \mathrm{O}_{5}$ & 90 & 201 & 33 & 19 & 23 & 321 & 656 & 110 & 85 & 87 \\
\hline & $\mathrm{Cr}_{2} \mathrm{O}_{3}$ & 88 & 266 & 2.6 & 24 & 29 & 454 & 2172 & bdl & 14 & 42 \\
\hline & $\mathrm{GaO}$ & 210 & 857 & 5.6 & 4.2 & 9 & 355 & 555 & 200 & 13 & 28 \\
\hline & $\mathrm{As}_{2} \mathrm{O}_{3}$ & 710 & 2809 & 107 & 2.6 & 181 & 318 & 1156 & 29 & 5.1 & 49 \\
\hline
\end{tabular}


Table 5. Cont

\begin{tabular}{|c|c|c|c|c|c|c|c|c|c|c|c|}
\hline \multirow[b]{2}{*}{ Unit } & \multirow[b]{2}{*}{ Elements } & \multicolumn{5}{|c|}{ Beirut } & \multicolumn{5}{|c|}{ Grozon } \\
\hline & & inc. av $n=24$ & inc. Max. & inc. Min. & $\begin{array}{l}\text { Colourless } \\
\text { Glass } n=7\end{array}$ & Blue Glass $n=27$ & inc. av $n=6$ & inc. Max. & inc. Min. & $\begin{array}{l}\text { Colourless } \\
\text { Glass } n=5\end{array}$ & Green Glass $n=8$ \\
\hline & $\mathrm{Rb}_{2} \mathrm{O}$ & 7.7 & 14 & 1.5 & 11 & 12 & 29 & 47 & 3.6 & 129 & 39 \\
\hline & $\mathrm{SrO}$ & 241 & 495 & 50 & 538 & 519 & 213 & 350 & 32 & 647 & 543 \\
\hline & $\mathrm{Y}_{2} \mathrm{O}_{3}$ & 6.2 & 12 & 1.6 & 9.2 & 9.3 & 8.4 & 19 & 0.74 & 17 & 17 \\
\hline & $\mathrm{ZrO}_{2}$ & 38 & 70 & 9.5 & 60 & 61 & 71 & 147 & 7.5 & 188 & 222 \\
\hline & $\mathrm{Nb}_{2} \mathrm{O}_{3}$ & 2.3 & 6.3 & 0.83 & 2.2 & 2.3 & 4.7 & 9.7 & 0.46 & 8.0 & 8.5 \\
\hline & $\mathrm{MoO}$ & 313 & 1238 & 13 & 0.66 & 6 & 20 & 36 & 4.4 & 1.4 & 5.2 \\
\hline & $\mathrm{Ag}$ & 7.1 & 77 & 0.023 & 0.057 & 0.46 & 3.8 & 6.8 & 0.76 & 0.089 & 10.3 \\
\hline & $\mathrm{Cd}$ & 0.10 & 0.49 & bdl & 0.027 & 0.049 & 0.088 & 0.30 & bdl & 0.59 & 0.24 \\
\hline & In & 57 & 372 & 1.6 & 0.020 & 4.9 & 17 & 47 & 3.7 & 0.51 & 0.62 \\
\hline & $\mathrm{SnO}_{2}$ & 100 & 439 & 5.3 & 3.9 & 21 & 1137 & 2844 & 304 & 161 & 166 \\
\hline & $\mathrm{Sb}_{2} \mathrm{O}_{3}$ & 118 & 343 & 12 & 3.5 & 45 & 87 & 155 & 25 & 16 & 135 \\
\hline & $\mathrm{Cs}_{2} \mathrm{O}$ & 0.094 & 0.51 & bdl & 0.10 & 0.12 & 1.9 & 3.6 & 0.38 & 3.8 & 2.8 \\
\hline & $\mathrm{BaO}$ & 124 & 239 & 36 & 242 & 233 & 209 & 271 & 87 & 585 & 330 \\
\hline & $\mathrm{La}_{2} \mathrm{O}_{3}$ & 5.1 & 12 & 1.2 & 8.4 & 8.5 & 8.5 & 20 & 0.66 & 25 & 23 \\
\hline & $\mathrm{CeO}_{2}$ & 10.4 & 25 & 2.9 & 16 & 16 & 17 & 41 & 0.91 & 46 & 42 \\
\hline & $\mathrm{PrO}_{2}$ & 1.2 & 2.7 & 0.26 & 1.9 & 2.0 & 1.9 & 4.5 & 0.14 & 5.5 & 5.0 \\
\hline & $\mathrm{Nd}_{2} \mathrm{O}_{3}$ & 4.7 & 10.7 & 1.1 & 7.8 & 7.9 & 7.0 & 17 & 0.50 & 22 & 19 \\
\hline & $\mathrm{Sm}_{2} \mathrm{O}_{3}$ & 1.03 & 2.54 & 0.31 & 1.6 & 1.6 & 1.4 & 3.3 & 0.11 & 4.2 & 3.6 \\
\hline & $\mathrm{Eu}_{2} \mathrm{O}_{3}$ & 0.24 & 0.53 & bdl & 0.46 & 0.46 & 0.34 & 0.73 & 0.094 & 0.95 & 0.81 \\
\hline & $\mathrm{Gd}_{2} \mathrm{O}_{3}$ & 0.84 & 2.0 & 0.0083 & 1.4 & 1.4 & 1.3 & 2.8 & 0.36 & 3.5 & 3.0 \\
\hline & $\mathrm{Tb}_{2} \mathrm{O}_{3}$ & 0.16 & 0.35 & 0.045 & 0.23 & 0.23 & 0.20 & 0.47 & 0.020 & 0.50 & 0.46 \\
\hline & $\mathrm{Dy}_{2} \mathrm{O}_{3}$ & 0.95 & 2.1 & 0.30 & 1.3 & 1.4 & 1.3 & 2.9 & 0.14 & 2.9 & 2.8 \\
\hline & $\mathrm{Ho}_{2} \mathrm{O}_{3}$ & 0.20 & 0.43 & 0.033 & 0.28 & 0.29 & 0.26 & 0.59 & 0.022 & 0.58 & 0.56 \\
\hline & $\mathrm{Er}_{2} \mathrm{O}_{3}$ & 0.55 & 1.2 & 0.16 & 0.76 & 0.76 & 0.77 & 1.7 & 0.015 & 1.6 & 1.6 \\
\hline & $\mathrm{Tm}_{2} \mathrm{O}_{3}$ & 0.080 & 0.17 & 0.025 & 0.10 & 0.11 & 0.12 & 0.26 & 0.022 & 0.22 & 0.23 \\
\hline & $\mathrm{Yb}_{2} \mathrm{O}_{3}$ & 0.56 & 1.16 & 0.068 & 0.71 & 0.72 & 0.78 & 1.8 & 0.065 & 1.7 & 1.6 \\
\hline & $\mathrm{Lu}_{2} \mathrm{O}_{3}$ & 0.087 & 0.19 & 0.022 & 0.10 & 0.11 & 0.12 & 0.26 & bdl & 0.23 & 0.23 \\
\hline & $\mathrm{HfO}_{2}$ & 0.90 & 1.7 & 0.23 & 1.3 & 1.4 & 1.5 & 2.9 & 0.28 & 4.2 & 4.8 \\
\hline & $\mathrm{Ta}_{2} \mathrm{O}_{3}$ & 0.13 & 0.34 & 0.038 & 0.12 & 0.12 & 0.24 & 0.52 & 0.013 & 0.46 & 0.50 \\
\hline & WO & 0.37 & 1.5 & 0.12 & 0.066 & 0.12 & 0.61 & 1.3 & 0.0080 & 1.0 & 1.5 \\
\hline & $\mathrm{Au}$ & 0.14 & 1.3 & bdl & 0.0015 & 0.016 & 0.021 & 0.042 & bdl & 0.0069 & 0.10 \\
\hline & $\mathrm{Bi}$ & 0.80 & 2.4 & 0.13 & 0.0074 & 0.83 & 0.54 & 1.4 & 0.12 & 0.061 & 0.45 \\
\hline & $\mathrm{ThO}_{2}$ & 1.1 & 3.1 & 0.38 & 1.1 & 1.1 & 2.6 & 6.2 & 0.12 & 6.3 & 6.7 \\
\hline & $\mathrm{UO}_{2}$ & 0.46 & 0.73 & 0.11 & 0.75 & 0.79 & 0.79 & 1.78 & 0.048 & 2.2 & 2.1 \\
\hline
\end{tabular}




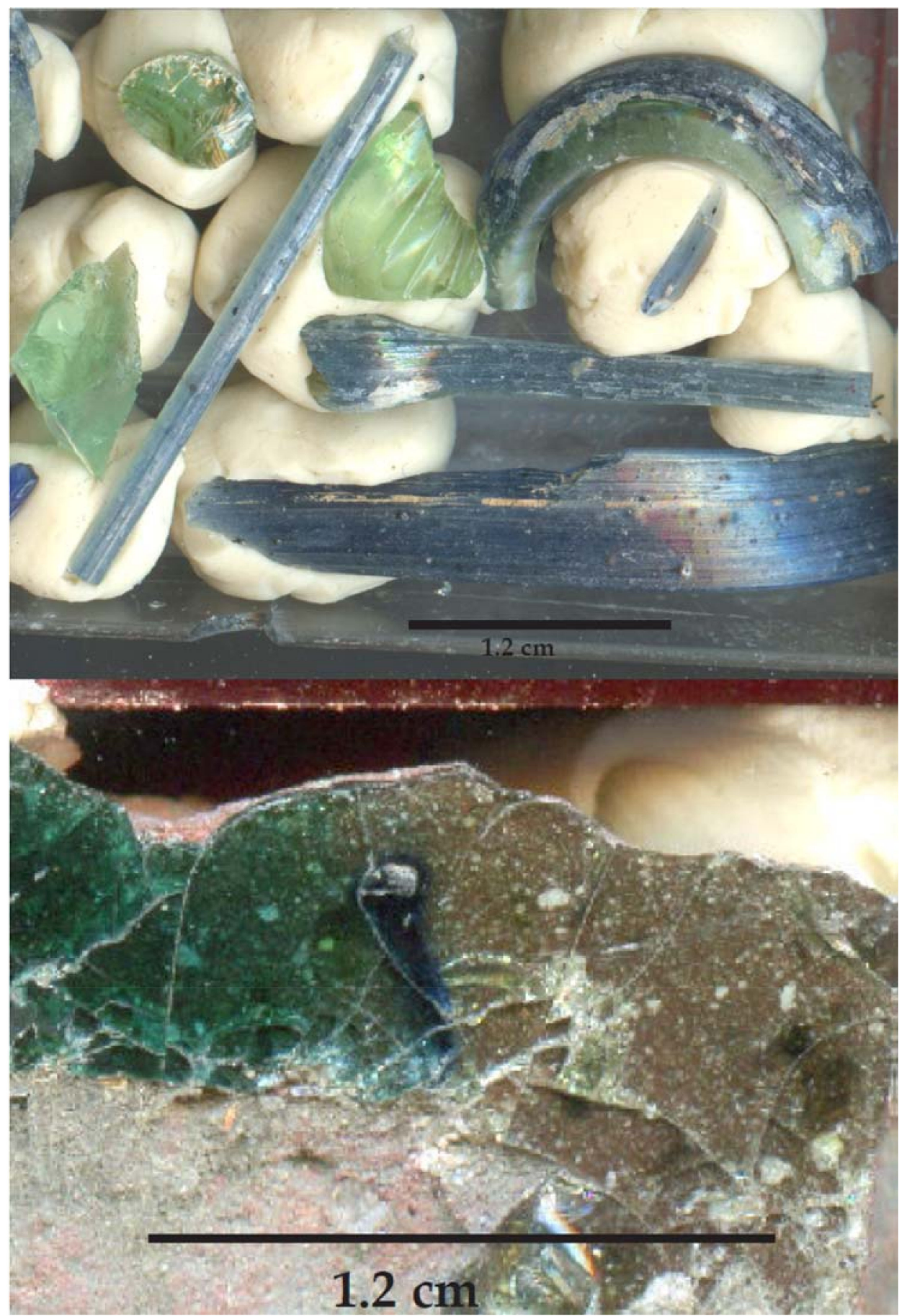

Figure 1. Cobalt colourant inclusions in the glass waste from Beirut (upper) and the crucible from Grozon (bottom). For Beirut several black inclusions the sizes of which range from some tens to some hundreds of micrometers were analysed, while for Grozon several analytical points were done on and around a larger inclusion which is approximate about $1 \mathrm{~mm}$ in diameter. 

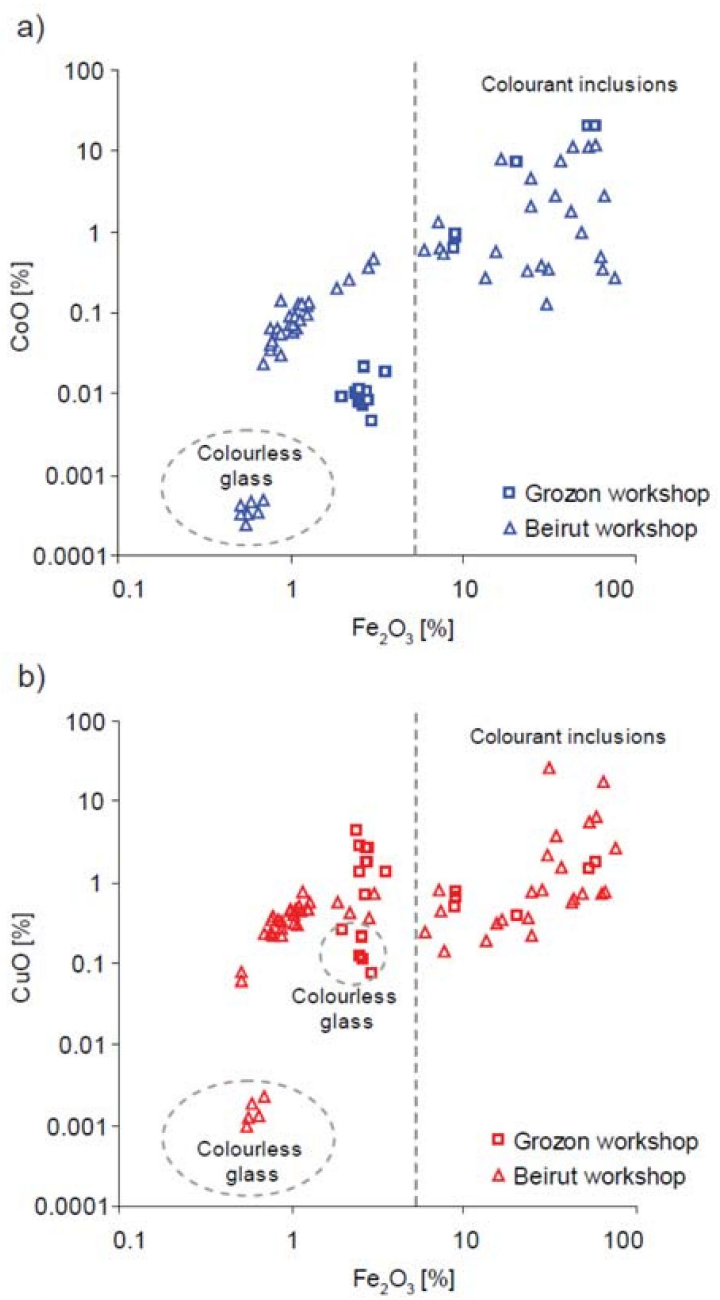

c)

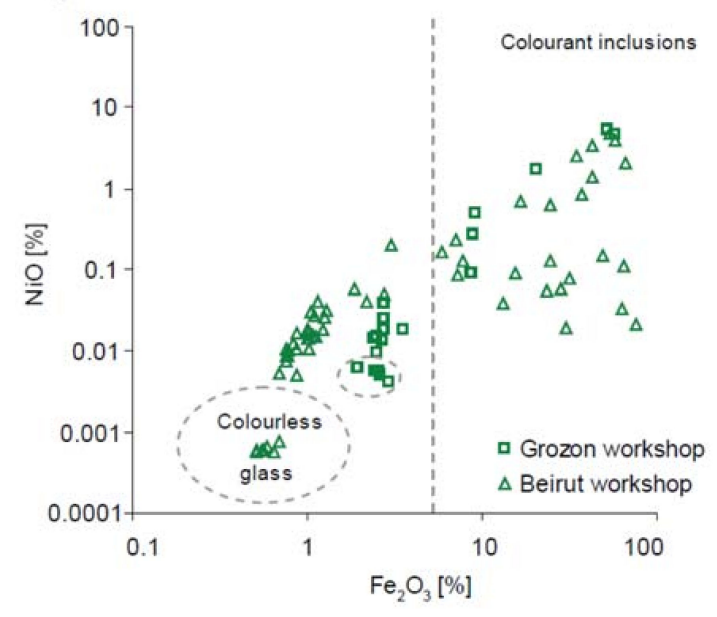

Figure 2. Metal oxides associated with the cobalt colorant in colorant inclusions, the cobalt blue and colourless glass from the seventh-century workshop in Beirut (Lebanon) and the crucible from the early eighth-century workshop at Grozon (France) [37]. The colorant inclusions consist mainly of iron oxide (right), associated with various amounts of cobalt, copper and nickel oxides. (a) Cobalt versus iron oxide concentrations show an overall higher cobalt content relative to the iron levels in the samples from Beirut as compared to the samples from Grozon; (b) copper oxide levels in relation to iron contents illustrate that part of the colorant inclusions detected in the crucible from Grozon contain more copper than iron; (c) nickel and iron concentrations highlight similarities between the two assemblages. 
a)

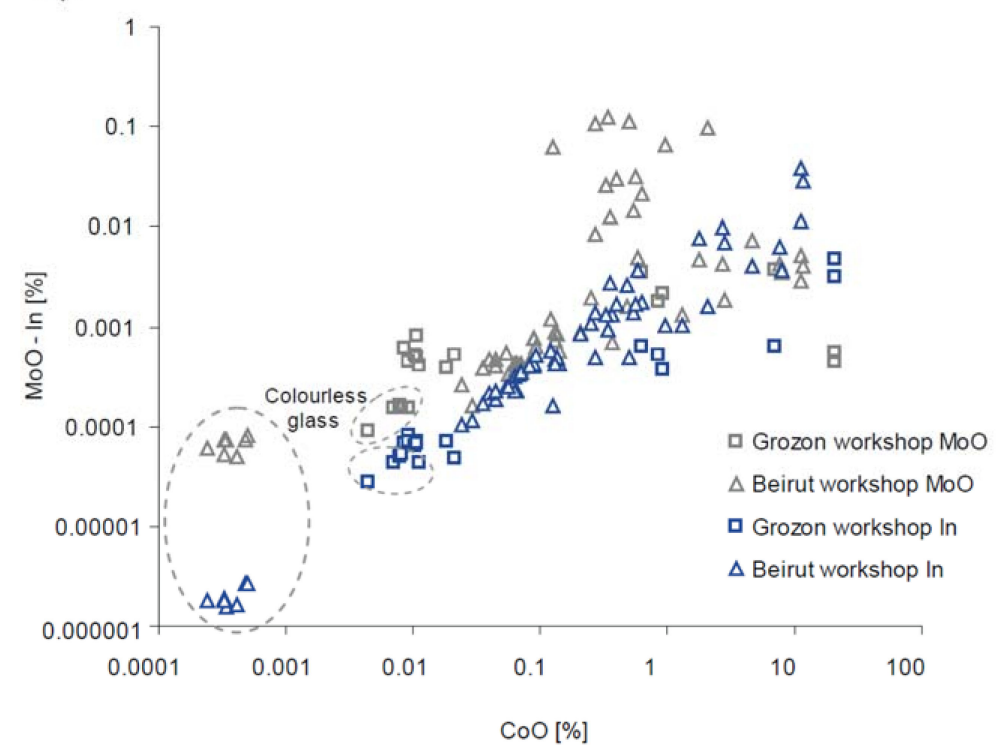

b)

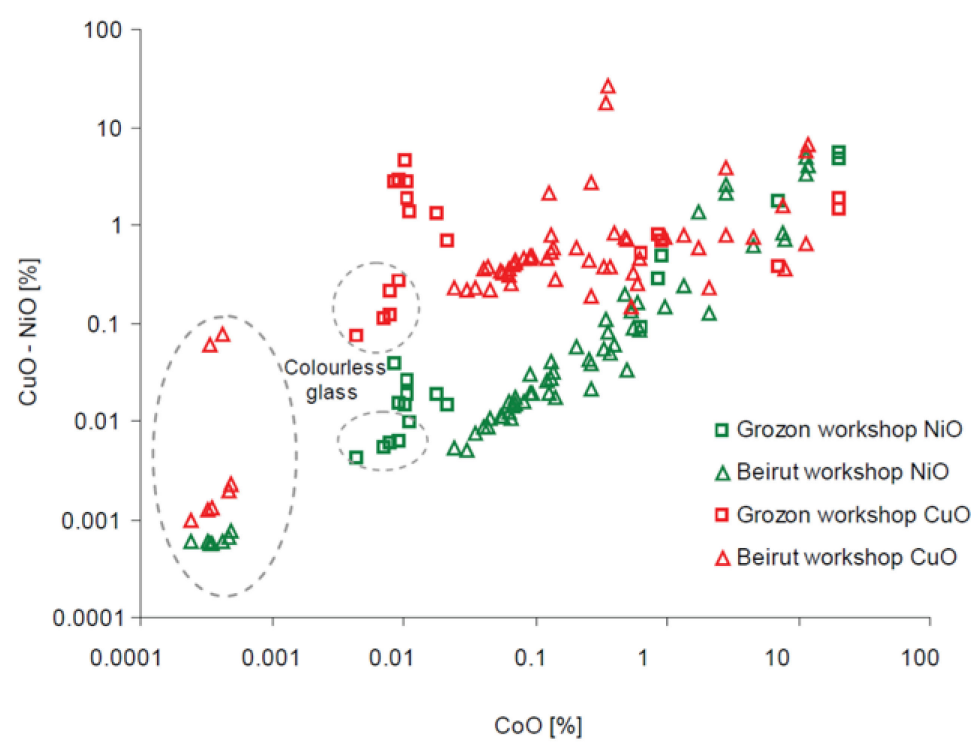

Figure 3. Elements associated with the cobalt colorant in colorant inclusions, cobalt blue and colourless glass from the Beirut and Grozon workshops. (a) Concentrations of molybdenum and indium versus cobalt contents exhibit clear positive correlation between cobalt and indium, whereas the correlation between cobalt and molybdenum is less evident. Only the systematic presence of MoO seems to be a typical feature of this cobalt source. (b) Comparison of copper and nickel versus cobalt contents shows a clear positive correlation between cobalt and nickel, while the copper contents are spread more widely relative to the cobalt concentrations. Dashed circles isolate the colourless glasses.

The remains of unfused cobalt colorant residues (about $1 \mathrm{~mm}$ in diameter, Figure 1) in a crucible recovered from the French site of Grozon (French Jura) and dating to the first half of the eighth century likewise reveal the presence of large amounts of iron, cobalt, nickel and copper oxides (Table 5). Several points within and around the cobalt rich inclusions have been analysed. While the cobalt concentrations vary from $0.64 \%$ to $20.8 \%$, the $\mathrm{CoO} / \mathrm{NiO}$ ratios are relatively confined $(1.9<\mathrm{CoO} / \mathrm{NiO}<7.2)$ with a median of 4.0 (Figure 4$)$. As such, this cobalt colorant is similar to the cobalt from the glass workshop in Beirut. In both cases, the ratios between cobalt and nickel, and to a lesser extent between cobalt and iron, are relatively homogeneous. All other element ratios display 
large variations and are therefore less suitable to establish the precise nature of the colorant from a chemical point of view (Figures 2 and 3). Only the quasi-systematic presence or absence of these metal oxides distinguishes the different types of colorant. Hence, the $\mathrm{CoO} / \mathrm{NiO}$ ratio represents the best parameter to define this post-Roman cobalt colorant and to trace the evolution of its supply during the late antique period (Figure 4).

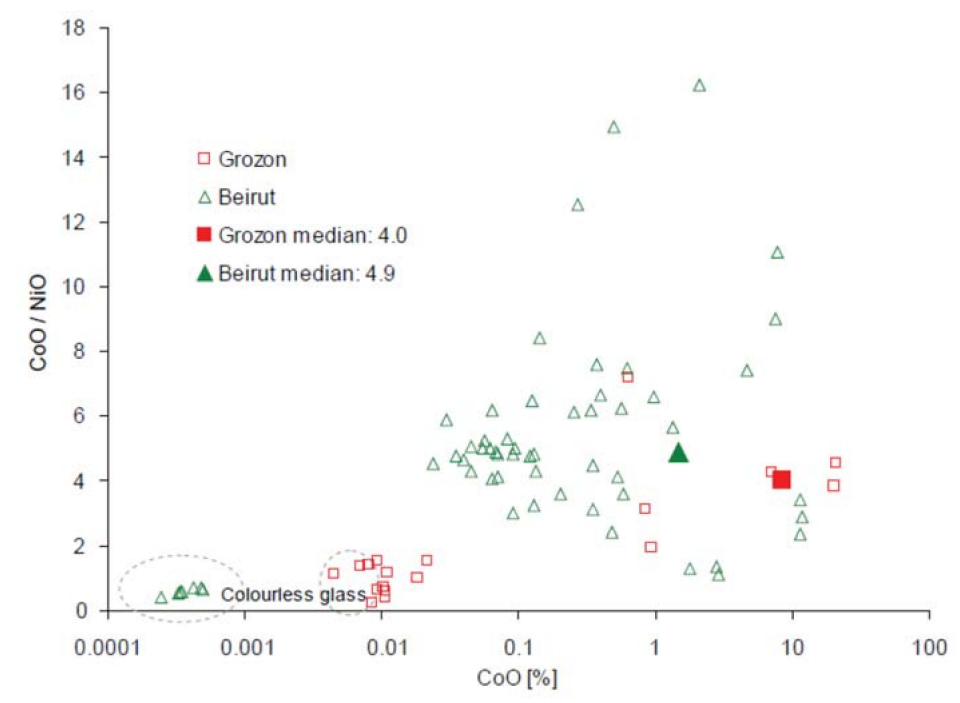

Figure 4. Variations of the cobalt to nickel ratios in relation to the absolute cobalt contents in the samples from Beirut and Grozon. With few exceptions, the cobalt to nickel ratios of the cobalt colorants are consistently low $(\mathrm{CoO} / \mathrm{NiO}<8)$.

Applying this criterion to the analytical data of first millennium glass assemblages from around the Mediterranean basin, geographical and chronological patterns can be recognised (Figure 5). Roman glasses from the first century BCE to the first half of the fourth century CE (Roman cage cups and mosaic glass, glass from the workshops at Le Pègue and Besançon) have usually high $\mathrm{CoO} / \mathrm{NiO}$ ratios $(24<\mathrm{CoO} / \mathrm{NiO}<54)$. After the end of the fourth century, the spectrum of the $\mathrm{CoO} / \mathrm{NiO}$ ratios is shifted towards lower values, while the variability increases. For example, cobalt blue Merovingian beads $(n=81)$ from different sites in France and Belgium (second half of the fifth century to the beginning of the eighth century) show a higher spread of $\mathrm{CoO} / \mathrm{NiO}$ ratios $(2<\mathrm{CoO} / \mathrm{NiO}<40)$ and a lower median of 11 [21,33,38]. Byzantine glass weights that belong to the so-called Foy-2 glass type $(n=59)$ attributed to the sixth and seventh centuries have a median $\mathrm{CoO} / \mathrm{NiO}$ ratio of about $8(3<\mathrm{CoO} / \mathrm{NiO}<23)$. The more or less contemporaneous Levantine I glass weights $(n=24)$ have an even lower median of 3.3 and a very narrow range $(2<\mathrm{CoO} / \mathrm{NiO}<5)$ [25]. Cobalt blue Viking beads and glass waste recovered from Ribe in Denmark ( $n=38$ ) dating mostly to the eighth century appear to break this pattern with a higher $\mathrm{CoO} / \mathrm{NiO}$ median of $17(5<\mathrm{CoO} / \mathrm{NiO}<30)$ [26]. The intensive recycling of Roman blue glasses and tesserae by Vikings craftsmen is probably responsible for this anomaly. Intriguingly, the tenth- to eleventh-century cobalt blue vessels decorated with white opaque glass (Saint Savin type) from numerous sites in France and Haithabu (Germany) (unpublished data) [24,34] have $\mathrm{CoO} / \mathrm{NiO}$ ratios that are much closer to those in Roman glasses $(24<\mathrm{CoO} / \mathrm{NiO}<54)$ and only very few of them exhibit $\mathrm{CoO} / \mathrm{NiO}$ ratios below 24 (Figure 5). Similarly, high ratios $(21<\mathrm{Co} / \mathrm{Ni}<24)$ have been measured in twelfth-century cobalt blue stained-glass windows from the Cathedral of Saint-Denis (unpublished data: $1.07 \% \mathrm{Fe}_{2} \mathrm{O}_{3}, 694 \mathrm{ppm} \mathrm{CoO}, 38 \mathrm{ppm} \mathrm{NiO}, 0.20 \% \mathrm{CuO}, 90 \mathrm{ppm} \mathrm{ZnO}$, corrected $\mathrm{CoO} / \mathrm{NiO}=21.5)$. These higher ratios are evidently the result of extensive recycling that was more common in western Europe than in the Near East. 


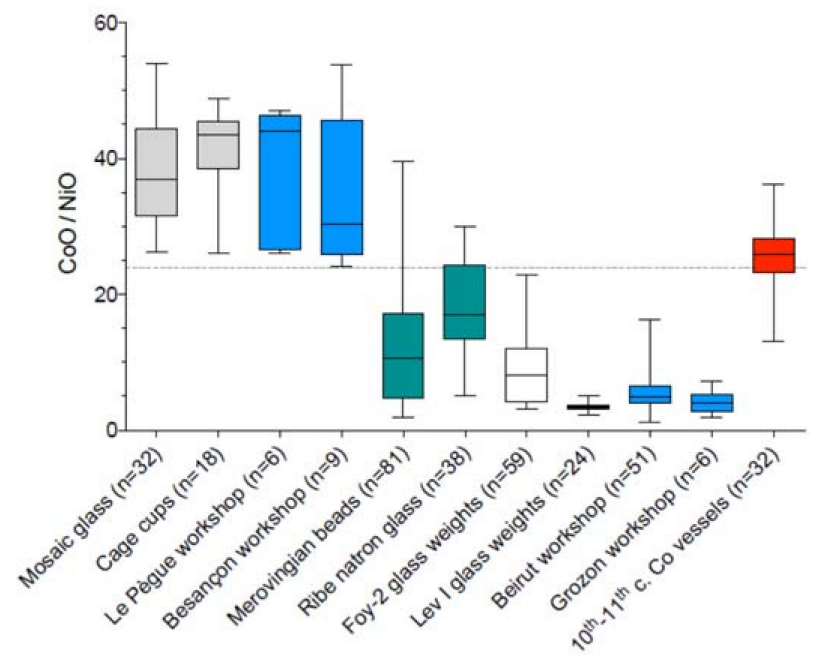

Figure 5. Chronological changes in the $\mathrm{CoO} / \mathrm{NiO}$ ratios of natron-type cobalt blue glasses ranging from the first century BCE (Roman mosaic glass) to the eleventh century CE (10th- to 11th-century cobalt blue vessels). Samples from before the end of the fourth century CE show $\mathrm{CoO} / \mathrm{NiO}$ ratios above 24 . In contrast, later glasses have typically lower $\mathrm{CoO} / \mathrm{NiO}$ ratios. This is particularly pronounced in the samples analysed from the workshops in Beirut and Grozon, but also in the Byzantine glass weights of the Levantine I type, while the Foy-2 glass weights as well as the Merovingian and Viking samples show a wider spread possibly due to recycling of earlier Roman glasses. Recycling probably underlies also the high $\mathrm{CoO} / \mathrm{NiO}$ ratios of a series of cobalt blue vessels dating to the tenth to eleventh century.

Taken together, these data provide strong evidence that new cobalt colorants with significantly lower $\mathrm{CoO} / \mathrm{NiO}$ ratios began to be exploited in the Near East at some time between the middle of the fourth and the early sixth century CE. This new cobalt compound progressively replaced the Roman cobalt. By the seventh century, it had become the predominant type of cobalt colorant in the eastern Mediterranean. In the western Mediterranean, however, this trend is less prominent. Even though the residues of cobalt colorants in the crucible from Grozon suggest that cobalt rich in nickel may have reached glass workshops in western Europe (recycling of glass containing these unmelted colorant inclusions cannot be excluded), earlier cobalt signatures persisted throughout the first and the beginning of the second millennium CE. This may be explained by the continuous recycling of ancient cullet, which is best exemplified by the data of the tenth- to eleventh-century cobalt blue vessels with opaque white glass decorations (Figure 5), and the compositional features of twelfth-century stained glass windows from numerous Gothic cathedrals.

\subsection{New European and Islamic Cobalt Sources}

Dramatic changes in the sources of cobalt occurred in western Europe at the end of the twelfth century, when cobalt mines in central Europe began to be exploited [11,39]. The European cobalt ore is associated with high zinc and elevated indium concentrations. The situation is different in the Islamic east as judged by the cobalt signatures of soda-rich plant ash glasses from the eight to eleventh centuries. The $\mathrm{CoO} / \mathrm{NiO}$ ratios of these glasses is relatively low. At the same time, zinc contents increase to the extent that their concentrations are equal or higher than those of cobalt [19-26]. This transformation is best reflected in the compositional characteristics of Islamic soda-ash glass weights from Egypt dating to the eight to twelfth century in contrast to Byzantine glass weights from the sixth and seventh centuries (Figure 6). All the Levantine I cobalt blue Byzantine weights have high nickel and low zinc contents, whereas most of the Egyptian glass weights have low nickel and high zinc concentrations. A few ninth-century Egyptian glass weights made using natron as the alkali source, as well as one tenth-century plant ash glass weight exhibit intermediate values, probably again due to recycling practices. 
a)
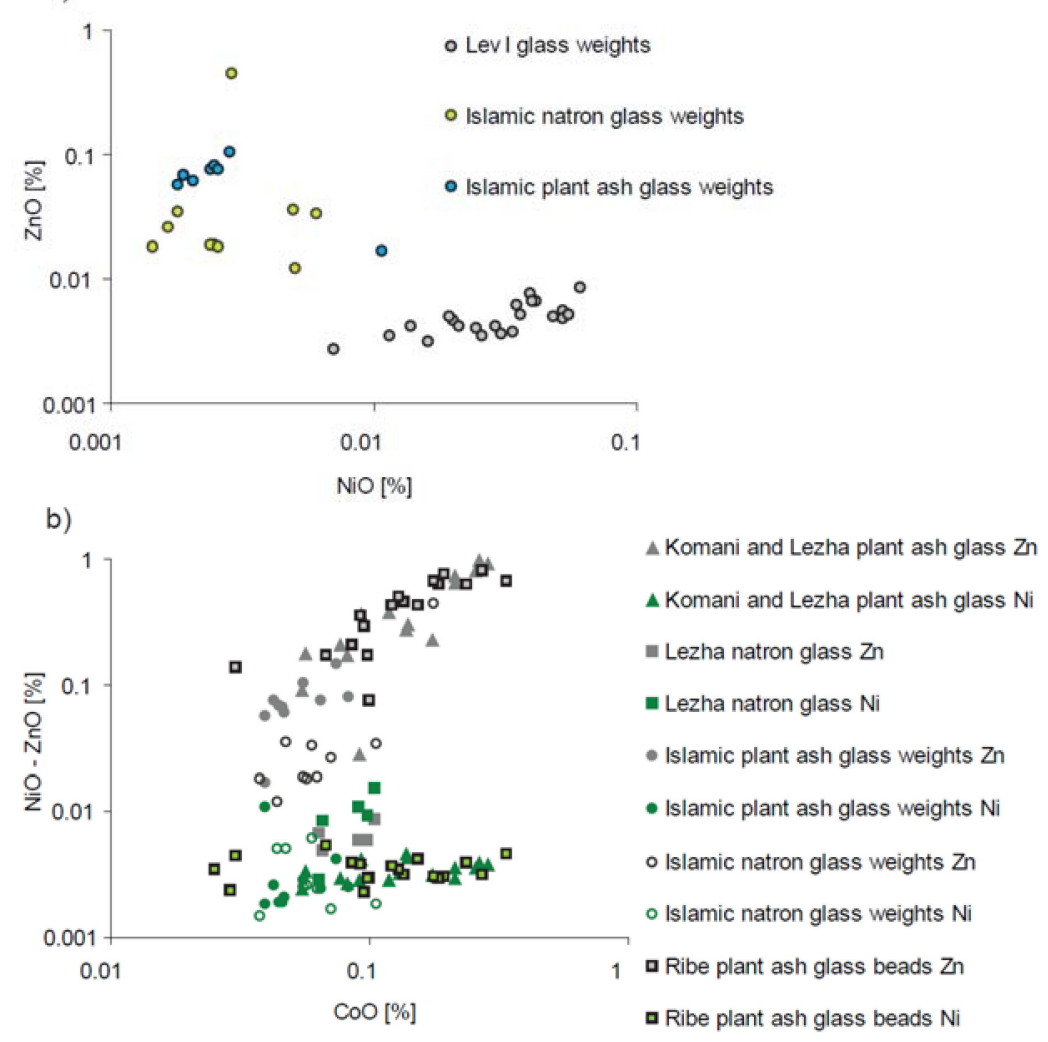

Figure 6. Evolution of zinc and nickel concentrations of cobalt blue glasses over time. (a) Zinc versus nickel contents of sixth- to seventh-century Byzantine glass weights of the Levantine I type and ninth- to tenth-century Islamic glass weights of both natron and plant-ash compositions show a sharp increase in zinc and decrease in nickel contents. (b) Zinc (greyscale) and nickel (green) concentrations in relation to cobalt contents in seventh-century natron blue glass beads from Lezha (Albania) and different Islamic natron and plant ash glasses from the eighth to thirteenth centuries. Whereas all the natron-type cobalt blue glasses have low zinc and relatively high nickel contents, almost all of the Islamic plant ash glasses have high zinc and low nickel levels. The intermediate concentrations of both eighth-century natron-type and some ninth-century plant-ash Islamic glass weights suggest a progressive change of cobalt sources during the eight and the recycling and mixing of ancient cobalt blue glasses during the ninth century CE.

That the chemical characteristics of the cobalt colorant in Islamic glass weights define a new type of cobalt ore is confirmed by analytical data of ninth- to tenth-century Islamic glass beads from Ribe ( $n=17$, Denmark) and Komani ( $n=12$, Albania), seventh- and thirteenth-centuries glass beads from Lezha ( $n=6$, Albania) [23], and cobalt blue bottles from ninth-century Samarra (Iraq) [35]. In all the Islamic cobalt blue plant ash glasses from Ribe, Komani (except one) and Samarra, cobalt is positively correlated with zinc and indium (Figure 7a). These glasses display low nickel and generally high lead concentrations (Table 6). Four of the five seventh-century beads from Lezha that were produced from cobalt blue natron glass have low zinc contents and $\mathrm{CoO} / \mathrm{NiO}$ ratios between 6 and 11 in line with a late antique cobalt source. A thirteenth-century bead from Lezha, in contrast, is an Islamic plant ash glass bead with a cobalt colorant associated with zinc, similar to the cobalt used in the beads from Ribe and Komani. According to our data, high zinc contents correlated with cobalt have not been identified in glass objects produced before the second half of the eighth century. It therefore seems likely that the earliest usage of this new cobalt source associated with zinc mineralization occurred during the second half of the eighth century. This new type of zinc-rich cobalt was to become the prevailing cobalt colorant in Islamic soda ash glasses between the ninth and the eleventh century, while some sporadic finds (plant ash bead from Lezha) point to its use possibly as late as the thirteenth century. 
Table 6. Average concentrations of the main elements associated with the cobalt ore used for ninth- to thirteenth-century Islamic plant ash glasses, and thirteenth-century European plant ash glasses shown in Figure 7.

\begin{tabular}{|c|c|c|c|c|c|c|c|c|c|c|c|c|}
\hline \multirow{2}{*}{ Samples } & \multicolumn{5}{|l|}{ wt $\%$} & \multicolumn{5}{|l|}{ ppm } & \multicolumn{2}{|c|}{ Average Ratios of Metal Oxides } \\
\hline & $\mathrm{Fe}_{2} \mathrm{O}_{3}$ & $\mathrm{CoO}$ & $\mathrm{NiO}$ & $\mathrm{CuO}$ & $\mathrm{ZnO}$ & $\mathrm{As}_{2} \mathrm{O}$ & ${ }_{3} \mathrm{MoO}$ & In & $\mathrm{SnO}_{2}$ & $\mathrm{PbO}$ & $\mathrm{CoO} / \mathrm{ZnO}$ & $\mathrm{CoO} / \mathrm{In}$ \\
\hline Komani and Lezha plant ash glass $(n=16)$ & 1.20 & 1492 & 34 & 1478 & 4209 & 8 & 3 & 2 & 368 & 540 & 0.58 & 852 \\
\hline $\mathrm{SD}(\sigma)$ & 0.25 & 764 & 6 & 609 & 3004 & 4 & 1 & 2 & 517 & 674 & & \\
\hline Komani unguentarium $(n=1)$ & 0.82 & 1050 & 24 & 1699 & 1605 & 11 & 1 & 40 & 459 & 1487 & 0.65 & 26.5 \\
\hline Ribe plant ash glass beads $(n=17)$ & 1.39 & 1483 & 36 & 2818 & 4285 & 17 & 2 & 2 & 174 & 451 & 0.40 & 846 \\
\hline $\mathrm{SD}(\sigma)$ & 0.42 & 794 & 8 & 4028 & 2283 & 25 & 1 & 1 & 288 & 571 & & \\
\hline Islamic plant ash glass weights $(n=10)$ & 1.64 & 537 & 33 & 2108 & 738 & 20 & 3 & 1 & 484 & 3932 & 0.88 & 874 \\
\hline $\mathrm{SD}(\sigma)$ & 0.47 & 153 & 27 & 1229 & 323 & 11 & 1 & 0 & 872 & 6261 & & \\
\hline 13th-14th-centuries French glass $(n=28)$ & 1.45 & 1623 & 46 & 3248 & 4943 & 40 & 2 & 123 & 193 & 2513 & 0.44 & 15.6 \\
\hline $\mathrm{SD}(\sigma)$ & 0.40 & 809 & 23 & 3494 & 3753 & 36 & 1 & 79 & 163 & 2199 & & \\
\hline
\end{tabular}




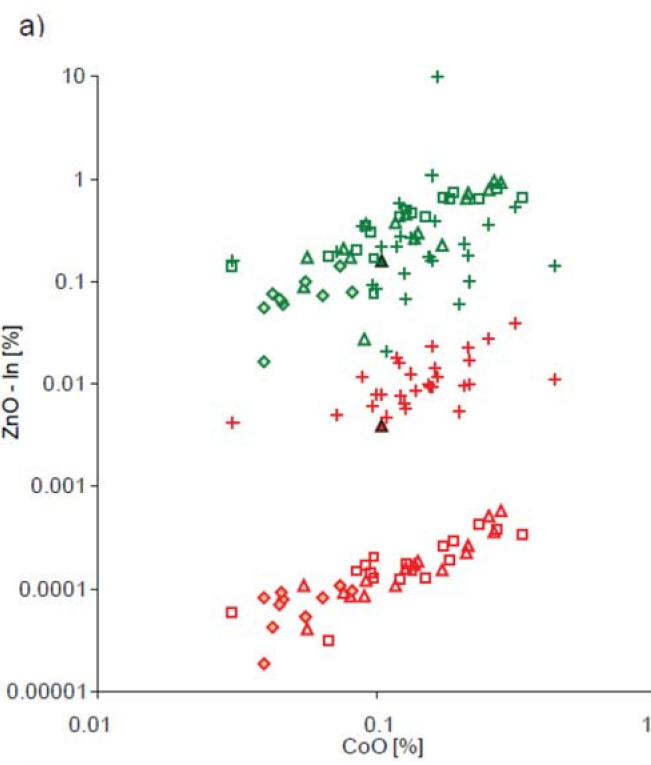

b)

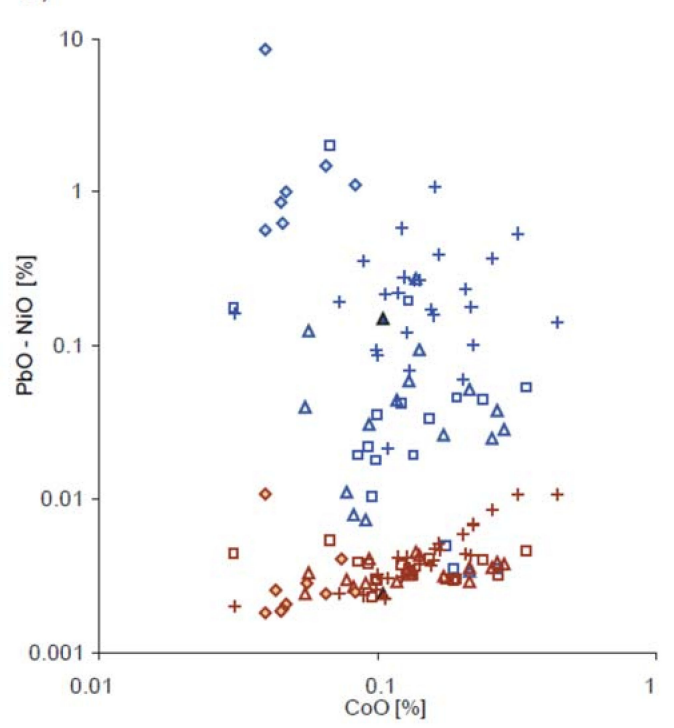

Komani and Lezha plant ash glass

$\Delta \mathrm{Zn} \quad \Delta \mathrm{In} \quad \Delta \mathrm{Pb} \quad \Delta \mathrm{Ni}$

Komani $13^{\text {th }} \mathrm{c}$. unguentarium

$\Delta \mathrm{Zn} \quad \Delta \mathrm{In} \quad \Delta \mathrm{Pb} \quad \Delta \mathrm{Ni}$

Ribe plant ash glass beads

$\square \mathrm{Zn} \quad \mathrm{In} \quad \square \mathrm{Pb} \quad \square \mathrm{Ni}$

Islamic plant ash glass weights

$\diamond \mathrm{Zn} \diamond \mathrm{In} \quad \diamond \mathrm{Pb} \diamond \mathrm{Ni}$

$13^{\text {th }}-14^{\text {th }}$ centuries French glass

$+\mathrm{Zn}+\mathrm{ln}+\mathrm{Pb}+\mathrm{Ni}$

Figure 7. Metal impurities associated with the cobalt source used in Islamic and European cobalt blue plant ash glasses between the ninth and the thirteenth century CE. (a) Zinc and indium contents in relation to cobalt highlight similarities and differences. While the two cobalt colorants share similar zinc concentrations, European glasses having significantly higher levels of indium than Islamic glasses. (b) Both lead and nickel concentrations of medieval European cobalt blue glasses are comparable to those of Islamic cobalt coloured glasses.

The question remains to what extent this Islamic zinc-rich cobalt is related to the European zincand indium-rich cobalt ores identified by Gratuze and colleagues in European glasses dating to the late twelfth century CE $[11,21,40]$. At first sight, European cobalt resembles the cobalt used in Islamic plant ash glasses from the ninth to the eleventh centuries. Both cobalt colorants have high zinc, low nickel and varying lead contents (Figure 7). However, if we consider indium concentrations alongside zinc, nickel and lead, the European cobalt blue glasses can be separated from Islamic cobalt coloured glasses. European glasses contain about 55 times more indium than Islamic glasses with a median value for $\mathrm{CoO} / \mathrm{In}$ ratios of 14.6 in European glasses compared to about 800 in Islamic samples. The median cobalt to zinc and $\mathrm{CoO} / \mathrm{NiO}$ ratios, in contrast, are similar between the two types of colorants (CoO/ZnO: 0.38 and $0.37 ; \mathrm{CoO} / \mathrm{NiO}: 35.9$ and 33.4, respectively). There is little doubt then that indium serves as 
a reliable marker to distinguish between the medieval European cobalt ore and the one exploited by Islamic glass makers. In light of these observations, a single thirteenth-century spindle-shaped unguentarium recovered from Komani has been coloured with Co-Zn-In European cobalt.

\section{Conclusions}

Despite its unique function as a colouring agent for vitreous materials and its potential to reveal supply networks in the ancient world due to its characteristic elemental signature, first millennium CE cobalt colorants have never been classified into distinct compositional groups. Using mostly correlations between cobalt, nickel and zinc, we were able to demonstrate two major changes in the chemical make-up of cobalt colorants during the late antique and early medieval period. Roman cobalt blue glasses show a relatively constant composition characterised by a high $\mathrm{CoO} / \mathrm{NiO}$ ratio $(\mathrm{CoO} / \mathrm{NiO}>24)$. This cobalt colorant seems to consist mainly of a mixture of iron, cobalt and copper oxides. Sometime between the late fourth and the beginning of the sixth century, the $\mathrm{CoO} / \mathrm{NiO}$ ratios experience a drastic decrease best illustrated by sixth- to seventh-century Levantine I glasses with very low $\mathrm{CoO} / \mathrm{NiO}$ ratios $(2.2<\mathrm{CoO} / \mathrm{NiO}<5.1)$. However, continuous recycling of ancient glass resulted in the persistence of earlier cobalt types throughout the first millennium CE. In the course of the second half of the eighth century CE, a new type of cobalt appeared in the eastern Mediterranean. This cobalt compound has elevated levels of zinc and low nickel contents and is characteristic of Islamic glass productions, particularly in combination with Islamic soda plant ash glass produced between the ninth and the eleventh centuries CE. The absence of significant levels of indium, distinguishes the Islamic zinc-rich cobalt unambiguously from the European zinc-rich cobalt that was used throughout the Mediterranean region from the end of the twelfth century onwards.

At present, there is not enough evidence to establish whether or not the late antique nickel-rich cobalt colorant is related to the discovery of a new cobalt deposit or simply to the exploitation of deeper mineral veins of the same deposit. Varying phases within the same deposit can potentially generate different compositional signatures such as oxidized minerals at the exposed surface (iron cap or gossan) compared to sulphide veins further below. In contrast, there can be no doubt that the fundamental change in the composition of the cobalt colorant during the eight century in Islamic glass-making reflect the exploitation of new cobalt deposits. The geographical location of this cobalt source remains yet to be found $[41,42]$.

Author Contributions: B.G. and N.S. conceived, designed and performed the experiments; B.G., I.P. and N.S. analysed the data; B.G. and N.S. wrote the paper.

Funding: This project has received funding from the European Research Council (ERC) under the European Union's Horizon 2020 research and innovation programme (grant agreement No. 647315 to NS). The funding organisation had role in the design of the study; in the collection, analyses, or interpretation of data; in the writing of the manuscript, and in the decision to publish the results.

Conflicts of Interest: The authors declare no conflict of interest.

\section{References}

1. Abe, Y.; Harimoto, R.; Kikugawa, T.; Yazawa, K.; Nishisaka, A.; Kawai, N.; Yoshimura, S.; Nakai, I. Transition in the use of cobalt-blue colorant in the New Kingdom of Egypt. J. Archaeol. Sci. 2012, 39, 1793-1808. [CrossRef]

2. Shortland, A.J.; Tite, M.S.; Ewart, I. Ancient exploitation and use of cobalt alums from the Western Oases of Egypt. Archaeometry 2006, 48, 153-168. [CrossRef]

3. Walton, M.; Eremin, K.; Shortland, A.; Degryse, P.; Kirk, S. Analysis of Late Bronze Age glass axes from Nippur-A new cobalt colourant. Archaeometry 2012, 54, 835-852. [CrossRef]

4. Huisman, D.; van der Laan, J.; Davies, G.; van Os, B.; Roymans, N.; Fermin, B.; Karwowski, M. Purple haze: Combined geochemical and Pb-Sr isotope constraints on colourants in Celtic glass. J. Archaeol. Sci. 2017, 81, 59-78. [CrossRef] 
5. Rolland, J. L'artisanat du Verre Dans le Monde Celtique du Second âge du Fer, Approches Archéométriques, Technologiques et Sociales. Ph.D. Thesis, Université Paris 1 Panthéon Sorbonne, Paris, France, 2017.

6. Dussubieux, L.; Gratuze, B. Origine et diffusion du verre dans le monde indien et en Asie du Sud-Est: L'importance du dosage des éléments-traces. Revue d'Archeometrie 2003, 27, 67-73. [CrossRef]

7. Kaczmarczyk, A. The source of cobalt in ancient Egyptian pigments. In Proceedings of the 24th International Archaeometry Symposium; Smithsonian Institution Press: Washington, DC, USA, 1986; pp. 369-376.

8. Gratuze, B.; Picon, M. Utilisation par l'industrie verrière des sels d'aluns des oasis égyptiennes au début du premier millénaire avant notre ére. In L'Alun de Mediterranie; Institut Français de Naples: Napoli, Italy, 2006; pp. 269-276.

9. Gratuze, B.; Billaud, Y. Inventaire des perles en verre et en faïence de l'Age du Bronze originaires des ateliers de la région de Frattesina retrouvées en France. In Atti delle XVI Giornate Nationali di Studio sul Vetro, Adria (RO), 12-13 May 2012; Ciappi, S., Larse, A., Uboldi, M., Eds.; Nazionale Italiano AIHV: Adria, Italy, 2014; pp. 25-38.

10. Dayton, J.E. Geological evidence for the discovery of cobalt blue glass in Mycenaean times as a by-product of silver smelting in the Schneeberg area of the Bohemian Erzgebirge. Revue d'Archéométrie 1981, 1, 57-61. [CrossRef]

11. Gratuze, B.; Soulier, I.; Blet, M.; Vallauri, L. De l'origine du cobalt: Du verre à la céramique. Revue d'Archéométrie 1996, 20, 77-94. [CrossRef]

12. Walton, M.S.; Shortland, A.; Kirk, S.; Degryse, P. Evidence for the trade of Mesopotamian and Egyptian glass to Mycenaean Greece. J. Archaeol. Sci. 2009, 36, 1496-1503. [CrossRef]

13. Varberg, J.; Gratuze, B.; Kaul, F.; Hansen, A.H.; Rotea, M.; Wittenberger, M. Mesopotamian glass from Late Bronze Age Egypt, Romania, Germany, and Denmark. J. Archaeol. Sci. 2016, 74, 184-194. [CrossRef]

14. Blomme, A.; Degryse, P.; Dotsika, E.; Ignatiadou, D.; Longinelli, A.; Silvestri, A. Provenance of polychrome and colourless 8th-4th century BC glass from Pieria, Greece: a chemical and isotopic approach. J. Archaeol. Sci. 2017, 78, 134-146. [CrossRef]

15. Gallo, F.; Silvestri, A.; Molin, G.; Marcante, A.; Guerriero, P. Iron Age vessels from the Archaeological Museum of Adria (North-Eastern Italy): a textural, chemical and mineralogical study. In Proceedings of the 39th International Symposium on Archaeometry, Leuven, Belgium, 28 May-1 June 2012; pp. 198-207.

16. Panighello, S.; Orsega, E.F.; van Elteren, J.T.; Šelih, V.S. Analysis of polychrome Iron Age glass vessels from Mediterranean I, II and III groups by LA-ICP-MS. J. Archaeol. Sci. 2012, 39, 2945-2955. [CrossRef]

17. Shortland, A.; Schroeder, H. Analysis of first millennium BC glass vessels and beads from the Pichvnari necropolis, Georgia. Archaeometry 2009, 51, 947-965. [CrossRef]

18. Oikonomou, A.; Henderson, J.; Gnade, M.; Chenery, S.; Zacharias, N. An archaeometric study of Hellenistic glass vessels: Evidence for multiple sources. Archaeol. Anthropol. Sci. 2018, 10, 97-110. [CrossRef]

19. Cherel, A.-F.; Gratuze, B.; Patrick, S. Les perles en faïence et en verre de l'âge du Bronze découvertes en Bretagne: Nouvelles données, nouvelles approches. Étude typo-chronologique, composition, provenance. BSPF 2018, in press.

20. Gratuze, B. Annexe. Étude chimique des verres de l'atelier de Beyrouth. Syria 2000, 11, 291-296. [CrossRef]

21. Gratuze, B.; Soulier, I.; Barrandon, J.-N.; Roy, D. De l'origine du cobalt dans les verres. Revue d'Archéométrie 1992, 16, 97-108. [CrossRef]

22. Neri, E.; Gratuze, B.; Schibille, N. Dating the mosaics of the Durres amphitheatre through interdisciplinary analysis. J. Cult. Heritage 2017, 28, 27-36. [CrossRef]

23. Neri, E.; Gratuze, B.; Schibille, N. The trade of glass beads in early medieval Illyricum: Towards an Islamic monopoly. Archaeol. Anthropol. Sci. 2018, 1-16. [CrossRef]

24. Pactat, I.; Hilberg, V.; Gratuze, B. The bowl glass sherds of Saint-Savin's type discovered at Haithabu: Analytical study. 2018; in press.

25. Schibille, N.; Meek, A.; Tobias, B.; Entwistle, C.; Avisseau-Broustet, M.; Da Mota, H.; Gratuze, B. Comprehensive chemical characterisation of Byzantine glass weights. PLoS ONE 2016, 11, e0168289. [CrossRef] [PubMed]

26. Sode, T.; Gratuze, B. Archaeometric studies of mediaevals glass finds (beads, tesserae, glass wastes and cullets) from Ribe (Denmark). 2018; in press.

27. Van Wersch, L.; Biron, I.; Neuray, B.; Mathis, F.; Chêne, G.; Strivay, D.; Sapin, C. Les vitraux alto-médiévaux de Stavelot (Belgique). ArchéoSciences 2014, 38, 219-234. [CrossRef] 
28. Gratuze, B. Glass characterization using laser ablation-inductively coupled plasma-mass spectrometry methods. In Recent Advances in Laser Ablation ICP-MS for Archaeology, Series: Natural Science in Archaeology; Dussubieux, L., Golitko, M., Gratuze, B., Eds.; Springer: Berlin/Heidelberg, Germany, 2016; pp. 179-196.

29. Nenna, M.-D.; Gratuze, B. Étude diachronique des compositions de verres employés dans les vases mosaïqués antiques: Résultats préliminaires. Annales du 17e Congrès de l'Association Internationale pour l'Histoire du Verre 2009, 17, 8-14.

30. Cholakova, A.; Rehren, T.; Gratuze, B.; Lankton, J. Glass coloring technologies of late Roman cage cups. J. Glass Stud. 2017, 59, 117-133.

31. Guérit, M.; Gratuze, B. Le mobilier en verre de deux ateliers de verriers antiques "Quartier des Prieurs" au Pègue (Drôme): Méthodologie et analyses. In L'artisanat Dans le Contexte de Recherche Archéologique Préventive: approches pluridisciplinaires. Actes de la Table-Ronde CORPUS: Etude du Mobilier Métallique et de l'instrument, Orléans, France, 2-3 Octorber 2014; Lusson, D., Roux-Capron, E., Eds.; Fédération archéologique du Loiret: Neuville-aux-Bois, France, 2016; pp. 43-50.

32. Munier, C.; Brkojewitsch, C. Premiers éléments relatifs à la découverte récente d'un atelier de verrier antique à Besançon. In Echanges et Commerce du Verre Dans le Monde Antique, Proceedings of the ACTES du Colloque de l'AFAV, Aix-en-Provence et Marseille, 7-9 Juin 2001; Foy, D., Nenna, M.-D., Eds.; Editions monique mergoil: Montagnac, France, 2003; pp. 321-337.

33. Mathis, F.; Vrielynck, O.; Degryse, P.; Gratuze, B. Production and exchange of glass beads in early medieval times. The case of the Bossut Gottechain (Belgium) Merovingian cemetery. 2018; in press.

34. Foy, D.; Gratuze, B.; Heijmans, M.; Roussel-Ode, J. Bleus et blancs: Verres de la fin de l'époque carolingienne en Provence. J. Glass Stud. 2017, 59, 153-169.

35. Schibille, N.; Meek, A.; Wypyski, M.T.; Kröger, J.; Rosser-Owen, M.; Wade Haddon, R. The glass walls of Samarra (Iraq): Ninth-century Abbasid glass production and imports. PLoS ONE 2018, in press.

36. Schibille, N.; Neri, E.; Ebanista, C.; Ammar, M.R.; Bisconti, F. Something old, something new: the late antique mosaics from the catacomb of San Gennaro (Naples). 2018; under review.

37. Billoin, D. Grozon (Jura). 5 rue de la Saline. Archéologie Médiévale 2015, 45, 290.

38. Brill, R.H. Scientific investigations of the Jalame glass and related finds. In Excavations at Jalame: Site of a Glass Factory in Late Roman Palestine; Weinberg, G.D., Ed.; University of Missouri: Columbia, MO, USA, 1988; pp. 257-291.

39. Bidegaray, A.I.; Pollard, A. Tesserae recycling in the production of medieval blue window glass. Archaeometry 2018. [CrossRef]

40. Zucchiatti, A.; Bouquillon, A.; Katona, I.; D'ALESSANDRO, A. The 'Della Robbia blue': a case study for the use of cobalt pigments in ceramics during the Italian Renaissance. Archaeometry 2006, 48, 131-152. [CrossRef]

41. Matin, M.; Pollard, A. From ore to pigment: a description of the minerals and an experimental study of cobalt ore processing from the Kāshān Mine, Iran. Archaeometry 2017, 59, 731-746. [CrossRef]

42. Matin, M.; Pollard, M. Historical accounts of cobalt ore processing from the Kashan mine, Iran. Iran J. Br. Inst. Persian Stud. 2015, 53, 171-183. [CrossRef]

(C) 2018 by the authors. Licensee MDPI, Basel, Switzerland. This article is an open access article distributed under the terms and conditions of the Creative Commons Attribution (CC BY) license (http://creativecommons.org/licenses/by/4.0/). 